J. Clin. Chem. Clin. Biochem.

Vol. 24, 1986, pp. 533-539

(C) 1986 Walter de Gruyter \& Co.

Berlin - New York

\title{
Enzymuria in Streptozotocin-Diabetic Rats
}

By H. Grötsch, M. Hropot, H. Kief and E. Klaus

Hoechst AG, Frankfurt/M.

(Received December 13, 1985/March 15, 1986)

Dedicated to E. v. Wasielewski, M.D., Professor of Medicinal Microbiology and Hygiene, on the occasion of his $65^{\text {th }}$ birthday

Summary: Twenty four hour urine samples of male control and streptozotocin-diabetic Wistar rats were analysed for a series of commonly known kidney-specific enzymes, for electrolytes, creatinine, glucose, total protein and urine volume. The examination was done during two periods of 5 days between the 25th and 30th and the 32nd and 36th day after streptozotocin application. In the first period the animals had free access to food and water, whereas in the second period on days 32,34 and 36 food was withdrawn. In the first observation period the diabetic rats showed increased excretion rates of 15 measured urinary parameters, while alanine aminopeptidase (EC 3.4.1.2) and $\gamma$-glutamyltransferase (EC 2.3.2.2) activities were lowered and inorganic phosphate was unchanged. The removal of food resulted in decreased excretion values for alanine aminopeptidase, $\gamma$-glutamyltransferase and total protein as compared with fasted nondiabetic animals. The activities of $\mathrm{N}$-acetyl- $\beta=D$-glucosaminidase (EC 3.2.1.30), acid phosphatase (EC 3.1.3.2), lactate dehydrogenase (EC 1.1.1.27), pyruvate kinase (EC 2.7.1.40), C1-fructose 1.6-diphosphatase (EC 3.1.3.11) and the excretion values for sodium, calcium, magnesium, chloride and glucose were higher than in fasted nondiabetic rats. $\beta$-Glucosidase (EC 3.2.1.21), potassium, inorganic phosphate, creatinine, and urine volume showed no differences between fasted diabetic and fasted control animals. The enzymes in the renal cortex at the end of the experiment showed only decreased activity of alanine aminopeptidase in diabetic rats. Lactate dehydrogenase, pyruvate kinase, $\beta$-glucosidase, $\mathrm{C} 1$-fructose 1.6 -diphosphatase and glucose 6 -phosphatase (EC 3.1.3.9) were increased and $\gamma$-glutamyltransferase, $\mathrm{N}$-acetyl- $\beta$ - $D$-glucosaminidase, acid phosphatase and glucose 6-phosphate dehydrogenase (EC 1.1.1.49) showed no change. The most remarkable microscopic finding in the kidneys of diabetic rats was glycogen storage in the cells of the straight cortical parts of the distal tubuli (Armanni-Ebstein cells). The polyuria induced glomerular hyperplasia, growth of glomerular capillaries and an increased size of filtration surface within the first days after streptozotocin application. An augmentation of PAS ${ }^{1}$ )-positive material in the glomerular mesangium was not observed at the end of the experiment. Insulin deficiency caused the metabolic, functional and structural abnormalities of the kidney.

\section{Enzymurie bei Streptozotocin-diabetischẹ Ratten}

Zusammenfassung: In 24-Stunden Sammelurinen von unbehandelten und Streptozotocin-diabetischen männlichen Wistarratten wurde die Ausscheidung einer Reihe nierenspezifischer Enzyme, von Elektrolyten, Kreatinin, Glucose, Gesamtprotein und das Harnvolumen untersucht. Die Harnproben wurden in zwei Periodẹn über jeweils 5 Tage zwischen dem 25. und 30. sowie dem 32. und 36. Tag nach der Streptozotocin-Injektion gesammelt. Im ersten Beobachtungszeitraum hatten die Tiere der Versuchs- und der Kontrollgruppe freien Zugang zu Futter und Wasser, während ihnen im zweiten Beobachtungszeitraum an den Tagen 32, 34 und

1) PAS: periodic acid Schiff reaction

J. Clin. Chem. Clin. Biochem. / Vol. 24, 1986 / No. 8 
36 das Futter entzogen wurde. Wasser war weiterhin ad libitum verfügbar. Im ersten Beobachtungszeitraum wurde in der Gruppe der diabetischen Tiere eine erhöhte Ausscheidung von 15 Kenngrößen im Urin gefunden, während die Aktivitäten von Alaninaminopeptidase (EC 3.4.1.2) und $\gamma$-Glutamyltransferase (EC 2.3.2.2) erniedrigt waren und anorganisches Phosphat unverändert blieb. Der Futterentzug führte bei diabetischen Tieren zu erniedrigten Werten für Alaninaminopeptidase, $\gamma$-Glutamyltransferase und $:$ Protein, während die Aktivitäten von N-Acetyl- $\beta$ - $D$-glucosaminidase (EC 3.2.1.30), saurer Phosphatase (EC 3.1.3.2), Lactatdehydrogenase (EC 1.1.1.27), Pyruvatkinase (EC 2.7.1.40), C1-Fructose-1.6-diphosphatase (EC 3.1.3.11) und die Elektrolyt- sowie Glucoseausscheidung gegenüber hungernden Kontrollratten höher lagen. Von den Enzymen im Rindengewebe wies die Alaninaminopeptidase eine erniedrigte Aktivität bei diabetischen Ratten auf. Die Aktivitäten von Lactatdehydrogenase, Pyruvatkinase, $\beta$-Glucosidase (EC 3.2.1.21), C1-Fructose-1.6-diphosphatase und Glucose-6-phosphatase (EC 3.1.3.9) stiegen an, während $\gamma$-Glutamyltransferase, N-Acetyl$\beta$ - $D$-glucosaminidase, saure Phosphatase und die Glucose-6-phosphatdehydrogenase (EC 1.1.1.49) keine Unterschiede zu den Kontrollen zeigten. Der auffälligste mikroskopische Nierenbefund bei diabetischen Tieren war eine Glykogenspeicherung in den Epithelien der geraden kortikalen Abschnitte der distalen Tubuli (Armanni-Ebstein-Zellen). Die Polyurie induzierte eine Hyperplasie der Glomeruli und ein Wachstum der glomerulären Kapillaren mit vergrößerter Filtrationsfläche in den ersten Tagen nach Verabreichung von Streptozotocin. Eine Vermehrung von $\mathrm{PAS}^{1}$ )-positivem Material im glomerulären Mesangium wurde am Versuchsende nicht festgestellt. Der Insulinmangel verursachte die metabolischen, funktionellen und strukturellen Abnormalitäten der Niere.

\section{Introduction}

Examination of the renal complications of diabetes is based on determination of enzymes in urine samples and in kidney tissue, excretion of electrolytes, creatinine, glucose, total protein, urine volume and on the morphological findings in the kidneys. Elevated excretion rates of certain enzymes in streptozotocin-diabetic rats have been recently reported (1). It has also been shown that in insulin and sulphonylurea-treated diabetic patients urinary $\mathrm{N}$-acetyl- $\beta-D$ glucosaminidase (2) and, in type I diabetics, serum and urinary $\mathrm{N}$-acetyl- $\beta-D$-glucosaminidase and urinary $\alpha$-glucosidase (EC 3.2.1.20) and $\beta$-galactosidase (EC 3.2.1.23) were elevated in comparison with nondiabetic individuals (3).

These results indicate that the disrupted metabolism in human and experimental diabetes leads to an overproduction of enzymes in both the kidney and other tissues, with a resulting increase in excretion. However, it is not yet clear whether there is any relationship between increased urinary and renal tissue levels of certain enzymes and vascular lesions in diabetic patients and animals made diabetic artificially. In acute experiments, treatment with insulin lowers the urinary activity of enzymes and normalizes metabolism (1).

The aim of the study was to find out if a correlation exists between urinary enzyme and electrolyte excretion on the one hand and functional and histological findings on the other in diabetic and normal Wistar rats. These investigations were performed either during free access to food and water or during shortterm fasting periods.

\section{Materials and Methods}

Diabetes was induced by injection of $65 \mathrm{mg} / \mathrm{kg}$ body weight of streptozotocin intravenously. The streptozotocin was dissolved in aqua bidest. Twenty four hour urine samples were collected from male control and diäbetic Wistar rats on five consecutive days from day 25 until 30 and day 32 until 36 after streptozzoto= cin application. Thymol was added to the urine collection vessels as a preservative. The animals were kept in individual metabolism cages and had free access to food (Altromin-1324) and water in the first period. In the second period food was removed for 24 hours every second day, on days 32, 34 and 36. The animals were divided in two groups:

1) A control group $(n=6)$ with an initial body weight of 133 $\pm 7 \mathrm{~g}$ and

2) A diabetic group $(n=6)$ with an initial body weight of 133 $\pm 4 \mathrm{~g}$.

One animal from the diabetic group did not develop polyuria and polydipsia and was excluded from statistical evaluation. Handling of the urine samples by centrifugation and gel filtration for the determination of enzymes has been described previously (4).

\section{Tissue preparation}

At the end of the experiment, the cortex of one kidney was separated from the medulla and prepared for the determination of enzymes. A sample of the organ $(300-400 \mathrm{mg})$ was homogenized with ice-cold $154 \mathrm{mmol} / \mathrm{l} \mathrm{NaCl}$ (Ultraturrax) for two periods of 30 seconds each. This was followed by a 20 -minute centrifugation $\left(15000 \mathrm{~min}^{-1}\right.$ at $\left.4^{\circ} \mathrm{C}\right)$. For gel filtration the aliquots were handled like urine samples. Only. activities of the soluble fractions of alanine aminopeptidase and $\gamma$-glutamyltransferase were taken into account. The other kidney was used for histological investigation. The pancreas of all animals was examined histologically in order to determine the reduction of $\beta$-cells.

Enzyme assays and measurement of glucose

Microliter methods were used for enzyme determinations. 
The continuous assays of alanine aminopeptidase, $\gamma$-glutamyltransferase, lactate dehydrogenase and the kinetic assay of glucose were performed with an Eppendorf ACP 5040 (Netheler and Hinz, Hamburg, FRG).

\begin{tabular}{|c|c|c|c|c|}
\hline & $\begin{array}{l}\text { Alanine } \\
\text { amino- } \\
\text { peptid- } \\
\text { ase }\end{array}$ & $\begin{array}{l}\gamma \text {-Glut- } \\
\text { amyl- } \\
\text { trans- } \\
\text { ferase }\end{array}$ & $\begin{array}{l}\text { Lactate } \\
\text { dehy- } \\
\text { drogen- } \\
\text { ase }\end{array}$ & Glucose \\
\hline Temperature ${ }^{\circ} \mathrm{C}$ & 25 & 25 & 25 & 25 \\
\hline Cycle (s) & 12 & 15 & 12 & 12 \\
\hline Wave length (nm) & 405 & 405 & 334 & 334 \\
\hline Factor & $657(y)$ & $1158(y)$ & $1052(y)$ & $8.33(x)$ \\
\hline Turn of rotor & 1 & 1 & 1 & 2 \\
\hline Flush position & 18 & 18 & 18 & 2 \\
\hline Start position & 5 & 12 & 3 & 12 \\
\hline \multicolumn{5}{|l|}{ Volumes $(\mu \mathrm{l})$} \\
\hline pos. 1 reagent & 250 & 250 & 250 & 250 \\
\hline pos. 2 sample & 50 & 25 & 50 & 25 \\
\hline pos. 5 substrate & 25 & 0 & 25 & 0 \\
\hline Linearity & $100 \mathrm{U} / 1$ & $250 \mathrm{U} / 1$ & $500 \mathrm{U} / 1$ & $70 \mathrm{mmol} / 1$ \\
\hline
\end{tabular}

(x) aqueous standard $8.33 \mathrm{mmol} / 1$ BMC Mannheim, FRG

(y) factor calculated from $V^{*} 1000 /\left(v^{*} E^{*} d\right)$

The following table includes the most significant steps in the analysis of pyruvate kinase, C1-fructose 1.6-diphosphatase and glucose 6-phosphate dehydrogenase in the Flexigem (ElectroNucleonics Inc., N. J., U.S. A.).

\begin{tabular}{|c|c|c|c|}
\hline & $\begin{array}{l}\text { Pyruvate } \\
\text { kinase }\end{array}$ & $\begin{array}{l}\text { C1-fructose } \\
\text { 1.6-diphos- } \\
\text { phatase }\end{array}$ & $\begin{array}{l}\text { Glucose } \\
\text { 6-phos- } \\
\text { phate } \\
\text { dehydro- } \\
\text { genase }\end{array}$ \\
\hline $\begin{array}{l}\text { Loading the } \\
\text { multicuvets outer inlet }\end{array}$ & Substrate & Substrate & Sample \\
\hline Inner inlet & $\begin{array}{l}\text { Sample + } \\
\text { reagent }\end{array}$ & $\begin{array}{l}\text { Sample }+ \\
\text { reagent }\end{array}$ & $\begin{array}{l}\text { Reagent }+ \\
\text { substrate }\end{array}$ \\
\hline $\begin{array}{l}\text { Wave length (nm) } \\
\text { Reaction } \\
\text { Incubation at } 25^{\circ} \mathrm{C} \\
\text { First reading (s) } \\
\text { Second reading (s) } \\
\text { Reading interval (s) } \\
\text { Number of readings } \\
\text { Factor }\end{array}$ & $\begin{array}{c}340 \\
\text { decreasing } \\
300 \mathrm{~s} \\
6 \\
10 \\
42 \\
19 \\
1032\end{array}$ & $\begin{array}{l}340 \\
\text { decreasing } \\
60 \mathrm{~s} \\
6 \\
10 \\
20 \\
19 \\
246.2\end{array}$ & $\begin{array}{c}340 \\
\text { increasing } \\
200 \mathrm{~s} \\
6 \\
60 \\
42 \\
19 \\
8095\end{array}$ \\
\hline Linearity (U/l) & 60 & 26 & 240 \\
\hline
\end{tabular}

In particular, the following tests were used:

\section{Alanine aminopeptidase and \\ $N$-acetyl- $\beta$ - $D$-glucosaminidase as described (4). \\ $\gamma$-Glutamyltransferase according to (5). \\ Lactate dehydrogenase}

Lactate dehydrogenase was determined by Merckotest according to 1. c. (6). The concentrations in the test were: phosphate $50 \mathrm{mmol} / 1 \mathrm{pH} 7.5$, NADH $0.18 \mathrm{mmol} / \mathrm{l}$, sodium pyruvate $0.6 \mathrm{mmol} / 1$, sample volume fraction 0.15 .

\section{Pyruvate kinase}

The pyruvate kinase assay (7) was adapted to the Flexigem at $25^{\circ} \mathrm{C}$ and $340 \mathrm{~nm}$. The concentrations in the incubation mixture were: triethanolamine $123 \mathrm{mmol} / \mathrm{l}$ containing $\mathrm{KCl} 92$ $\mathrm{mmol} / \mathrm{l}, \mathrm{MgSO}_{4} 16 \mathrm{mmol} / \mathrm{l}$ and EDTA $10 \mathrm{mmol} / \mathrm{l} \mathrm{pH} 7.5$, phosphoenolpyruvate $1 \mathrm{mmol} / \mathrm{l}$, lactate dehydrogenase ca. 17 U/l, NADH $0.18 \mathrm{mmol} / 1$, ADP $3 \mathrm{mmol} / \mathrm{l}$, sample volume fraction 0.15 .

\section{C1-Fructose 1.6-diphosphatase}

C1-fructose 1.6-diphosphatase was determined at $25^{\circ} \mathrm{C}$ and $340 \mathrm{~nm}(8)$. The assay was modified for the Flexigem.

The concentrations in the incubation mixture were: tris 110 mmol/1 pH 7.5, NADP $0.53 \mathrm{mmol} / 1,2$-mercaptoethanol 25 $\mathrm{mmol} / \mathrm{l}$, fructose 1,6-diphosphate $0.32 \mathrm{mmol} / \mathrm{l}$, phosphoglucose isomerase ca. $8 \mathrm{U} / 1$, glucose 6-phosphate dehydrogenase ca. $2 \mathrm{U} / \mathrm{l}$, magnesium chloride $11 \mathrm{mmol} / \mathrm{l}$, sample volume fraction 0.64 .

\section{Glucose 6-phosphate dehydrogenase}

Glucose 6-phosphate dehydrogenase was determined at $25^{\circ} \mathrm{C}$ and $340 \mathrm{~nm}(9)$. The concentrations in the test were:

tris $50 \mathrm{mmol} / \mathrm{l} \mathrm{pH} 7.5$, glucose 6-phosphate $3.3 \mathrm{mmol} / 1$, NADP $0.38 \mathrm{mmol} / \mathrm{l}$, magnesium chloride $6.3 \mathrm{mmol} / \mathrm{l}$, sample volume fraction 0.02 .

\section{Acid phosphatase}

Acid phosphatase was determined by a two-point reaction at $37^{\circ} \mathrm{C}$ and $405 \mathrm{~nm}(10,11)$.

The concentrations in the test were:

citrate $39 \mathrm{mmol} / 1 \mathrm{pH} \mathrm{5.2,} \mathrm{4-nitrophenylphosphate} 4.2 \mathrm{mmol} / 1$, $0.09 \mathrm{mmol} / \mathrm{l}$ albumin, sample volume fraction 0.17 . The reaction was stopped by adding $\mathrm{NaOH} 0.02 \mathrm{~mol} / \mathrm{l}$, ten times the volume of the incubation mixture.

\section{$\beta$-Glucosidase}

$\beta$-Glucosidase was determined by a two point method at $37^{\circ} \mathrm{C}$ and $405 \mathrm{~nm}$ (12). The concentrations in the incubation mixture were: mixed citrate $46 \mathrm{mmol} / 1$ and phosphate $34 \mathrm{mmol} / \mathrm{l}, \mathrm{pH}$ 5.5 , 4-nitrophenyl- $\beta$ - $D$-glucopyranoside $2.5 \mathrm{mmol} / \mathrm{l}$, sample volume fraction 0.20 .

The reaction was stopped by adding sodium carbonate $1 \mathrm{~mol} / \mathrm{l}$, four times the volume of the incubation mixture.

\section{Glucose 6-phosphatase}

Glucose 6-phosphatase was determined by a two point reading at $37^{\circ} \mathrm{C}$ and $700 \mathrm{~nm}$ (13). The concentrations in the test were: sucrose $62.5 \mathrm{mmol} / \mathrm{l}$, EDTA $0.25 \mathrm{mmol} / 1$, glucose 6-phosphate $25 \mathrm{mmol} / \mathrm{l}$, kacodylate $25 \mathrm{mmol} / \mathrm{l} \mathrm{pH} \mathrm{6.5,} \mathrm{sample} \mathrm{volume} \mathrm{frac-}$ tion 0.25 . The reaction was stopped by adding a mixture of trichloroacetic acid $0.62 \mathrm{~mol} / 1$ and ascorbic acid $0.11 \mathrm{~mol} / \mathrm{l}$

The determination of sodium, potassium, calcium and magnesium was performed with a Zeiss FL6 (combined flame photometer and atomic absorption), chloride with a Marius autochlor-o-counter (Kipp and Zonen, the Netherlands) and inorganic phosphate with molybdate/ $\mathrm{SnCl}_{2}$ (Technicon Autoanalyzer II). Glucose in blood and urine samples was kinetically determined with the BMC gluco-quant (hexokinase/glucose 6phosphate dehydrogenase) test combination using the Eppendorf ACP 5040. Creatinine was determined kinetically by the Jaffe method in the Flexigem using the BMC test combination. Protein determination was performed by laser nephelometry. 
Statistical evaluation

Data presented in tables 1 and 2 consist of the median values from 6 and 5 animals respectively, for 5 days in the first observation period. In the second period the values for 3 days with food or 2 days without food were appropriately averaged. The results presented in tables $1-3$ are median \pm standard error of the median values. For statistical evaluation the nonparametric Mann-Whitney, U-test was used (19).

\section{Results}

The five diabetic rats listed in the tables showed severe reduction of $\beta$-cells in the islets of Langerhans. Some islets contained one or two $\beta$-cells per section, while most contained no histologically detectable $\beta$ cells. The blood glucose concentration of these animals amounted to $25.62 \pm 2.11 \mathrm{mmol} / \mathrm{l}$ at the end of the experiment. The kidneys displayed marked glycogen deposition in the cells of the straight cortical parts of the distal tubuli, the so-called ArmanniEbstein cells (fig. 1). The glomeruli appeared to be slightly enlarged. An increase in PAS ${ }^{1}$ )-positive material in the mesangium was not observed. In the islets of the remaining animal from this group, a reduction of $\beta$-cells to about 20 percent of the normal incidence was found. This animal showed a slight hyperglycaemia of $13.95 \mathrm{mmol} / 1$, moderate glucosuria and minimal glycogen deposition in the corresponding tubular cells (fig. 2). Therefore, urinary and renal tissue parameters measured for this animal were not included in the statistical evaluation.

The clinical chemical results are shown in tables $1-3$. As demonstrated in table 2, weight gains between the two groups differ significantly. From the start of the experiment until day 25 , body weights of control animals increased by about $140 \mathrm{~g}$ and those of diabetic rats only by about $80 \mathrm{~g}$. In the first observation period the excretion rates of alanine aminopeptidase and $\gamma$-glutamyltransferase activities were significantly decreased within the diabetic group, whereas the excretion of inorganic phosphate was comparable in both groups. All other urinaryi parameters were significantly elevated in diabetic rats compared with control animals.

In the second observation period on days 32,34 and 36 without food, excretion rates in the diabetic group were significantly decreased for alanine aminopeptidase, $\gamma$-glutamyltransferase and total protein compared with fasted non-diabetic animals, whereas the activities of $\mathrm{N}$-acetyl- $\beta$ - $D$-glucosaminidase, acid phosphatase, lactate dehydrogenase, pyruvate kinase, C1-fructose 1.6-diphosphatase and the excretion values for sodium, calcium, magnesium, chloride and glucose were significantly higher than in fasted nondiabetic rats. No differences were seen for $\beta$-glucosidase, potassium, inorganic phosphate and creatinine between fasted diabetic and fasted control animals.

In the control group, food deprivation caused a reduction of excretion rates of alanine aminopeptidase, $\gamma$-glutamyltransferase, $\beta$-glucosidase, pyruvate kinase and C1-fructose 1.6-diphosphatase. Sodium, potassium, magnesium, chloride, total protein and glucose were reduced on days without food, whereas the urine volumes and the excretion of inorganic phosphate increased on these days.

Analysis of the renal cortex enzymes of both groups (tab. 3) indicated significant differences in alanine aminopeptidase, lactate dehydrogenase, $\beta$-glucosidase, pyruvate kinase, $\mathrm{C} 1$-fructose 1.6-diphosphatase and glucose 6-phosphatase. Activities of alanine aminopeptidase were lower, and those of lactate dehydrogenase and pyruvate kinase as well as of $\beta$-glucosi-

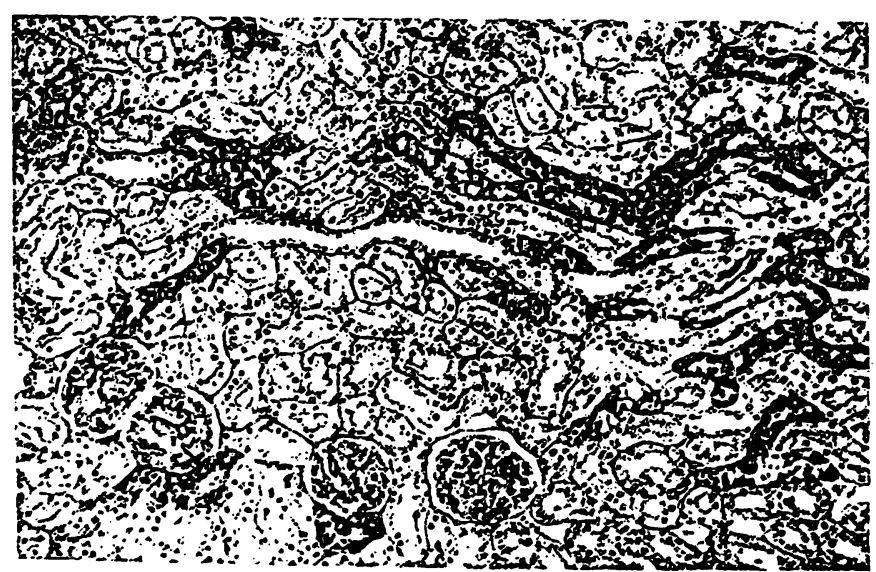

Fig. 1. Kidney showing marked glycogen storage in cells of the straight cortical parts of distal tubuli. 42 days after streptozotocin application. PAS-stain. $\times 75$

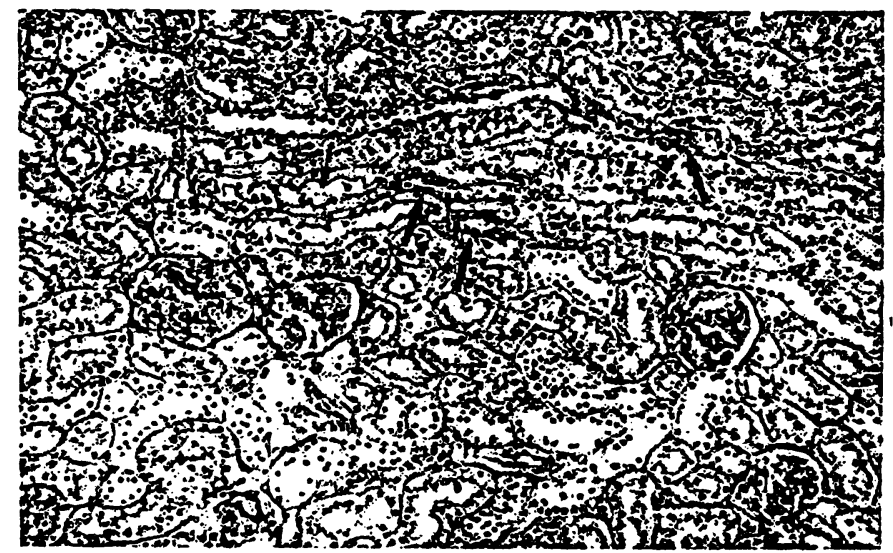

Fig. 2. Minimal glycogen deposition in isolated cells of the straight cortical parts of distal tubuli (arrows). Mild streptozotocin-induced diabetes. PAS-Stain. $\times 75$ 
Tab. 1. Excretion of urinary enzymes in male control and streptozotocin-diabetic Wistar rats.

\begin{tabular}{|c|c|c|c|c|c|c|}
\hline & \multicolumn{2}{|l|}{ First period } & \multicolumn{4}{|c|}{ Second period } \\
\hline & $\begin{array}{l}\text { control } \\
\mathrm{n}=6^{\text {group }}\end{array}$ & $\begin{array}{l}\text { diabetic } \\
\mathbf{n}=5\end{array}$ & $\begin{array}{l}\text { control } \\
\text { fed }\end{array}$ & $\begin{array}{l}\text { roup } \\
\text { fasted }\end{array}$ & $\begin{array}{l}\text { diabetic grou } \\
\text { fed }\end{array}$ & fasted \\
\hline $\begin{array}{l}\text { Alanine aminopeptidase } \\
\mathrm{mU} \cdot \mathrm{kg}^{-1} \cdot \mathrm{d}^{-1}\end{array}$ & $\begin{array}{r}909 \\
169\end{array}$ & $\begin{array}{c}\left.654^{*}\right) \\
83\end{array}$ & $\begin{array}{r}1030 \\
113\end{array}$ & $\begin{array}{r}603 \\
55\end{array}$ & $\begin{array}{r}1012 \\
676\end{array}$ & $\begin{array}{l}\left.394^{* * *}\right) \\
74\end{array}$ \\
\hline $\begin{array}{l}\gamma \text {-Glutamyltransferase } \\
\mathbf{U} \cdot \mathbf{k g}^{-1} \cdot \mathbf{d}^{-1}\end{array}$ & $\begin{array}{r}19.43 \\
\pm \quad 2.39\end{array}$ & $\begin{array}{l}\left.6.26^{*}\right) \\
0.47\end{array}$ & $\begin{array}{r}22.61 \\
3.21\end{array}$ & $\begin{array}{r}15.24 \\
1.97\end{array}$ & $\begin{array}{l}\left.13.90^{* *}\right) \\
2.79\end{array}$ & $\begin{array}{l}\left.10.31^{* * * *}\right) \\
2.94\end{array}$ \\
\hline $\begin{array}{l}\text { N-Acetyl- } \beta-D \text {-glucosaminidase } \\
\mathrm{mU} \cdot \mathrm{kg}^{-1} \cdot \mathrm{d}^{-1}\end{array}$ & $\begin{array}{r}637 \\
72\end{array}$ & $\begin{array}{c}\left.3986^{*}\right) \\
560\end{array}$ & $\begin{array}{l}793 \\
271\end{array}$ & $\begin{array}{l}571 \\
137\end{array}$ & $\begin{array}{l}\left.7018^{* *}\right) \\
833\end{array}$ & $\begin{array}{l}\left.1630^{* * *}\right) \\
162\end{array}$ \\
\hline $\begin{array}{l}\text { Acid phosphatase } \\
\mathrm{mU} \cdot \mathrm{kg}^{-1} \cdot \mathrm{d}^{-1}\end{array}$ & $\pm \begin{array}{r}2843 \\
600\end{array}$ & $\begin{array}{c}\left.21736^{*}\right) \\
3002\end{array}$ & $\begin{array}{r}3171 \\
900\end{array}$ & $\begin{array}{r}2103 \\
304\end{array}$ & $\begin{array}{l}\left.33351^{* *}\right) \\
7370\end{array}$ & $\begin{array}{l}\left.4627^{* * *}\right) \\
888\end{array}$ \\
\hline $\begin{array}{l}\text { Lactate dehydrogenase } \\
\mathrm{mU} \cdot \mathbf{k g}^{-1} \cdot \mathrm{d}^{-1}\end{array}$ & $\pm \begin{array}{r}465 \\
332\end{array}$ & $\begin{array}{c}\left.4376^{*}\right) \\
360\end{array}$ & $\begin{array}{r}384 \\
93\end{array}$ & $\begin{array}{l}374 \\
126\end{array}$ & $\begin{array}{l}\left.7707^{* *}\right) \\
1920\end{array}$ & $\begin{array}{l}\left.987^{* * *}\right) \\
175\end{array}$ \\
\hline $\begin{array}{l}\beta \text {-Glucosidase } \\
\mathrm{mU} \cdot \mathbf{k g}^{-1} \cdot \mathrm{d}^{-1}\end{array}$ & $\begin{array}{r}121 \\
25\end{array}$ & $\begin{array}{c}\left.1140^{*}\right) \\
172\end{array}$ & $\begin{array}{r}184 \\
44\end{array}$ & $\begin{array}{l}19 \\
10\end{array}$ & $\begin{array}{l}2241 * *) \\
353\end{array}$ & $\begin{array}{l}42 \\
17\end{array}$ \\
\hline $\begin{array}{l}\text { Pyruvate kinase } \\
\mathrm{mU} \cdot \mathrm{kg}^{-1} \cdot \mathrm{d}^{-1}\end{array}$ & $\pm \begin{array}{r}532 \\
119\end{array}$ & $\begin{array}{c}\left.5936^{*}\right) \\
370\end{array}$ & $\begin{array}{l}782 \\
136\end{array}$ & $\begin{array}{r}346 \\
81\end{array}$ & $\begin{array}{l}\left.9133^{* *}\right) \\
962\end{array}$ & $\begin{array}{l}\left.555^{* * *}\right) \\
100\end{array}$ \\
\hline $\begin{array}{l}\text { C1 Fructose 1.6-diphosphatase } \\
\mathrm{mU} \cdot \mathrm{kg}^{-1} \cdot \mathrm{d}^{-1}\end{array}$ & $\begin{array}{r}130 \\
24\end{array}$ & $\begin{array}{c}\left.1567^{*}\right) \\
205\end{array}$ & $\begin{array}{r}139 \\
39\end{array}$ & $\begin{array}{r}24 \\
3\end{array}$ & $\begin{array}{c}\left.1578^{* *}\right) \\
174\end{array}$ & $\begin{array}{l}153 * * *) \\
34\end{array}$ \\
\hline $\begin{array}{l}\text { Glucose 6-phosphatase } \\
\mathrm{mU} \cdot \mathrm{kg}^{-1} \cdot \mathrm{d}^{-1}\end{array}$ & 0 & 0 & 0 & 0 & 0 & 0 \\
\hline $\begin{array}{l}\text { Glucose 6-phosphate dehydrogenase } \\
\mathrm{mU} \cdot \mathrm{kg}^{-1} \cdot \mathrm{d}^{-1}\end{array}$ & 0 & 0 & 0 & 0 & 0 & 0 \\
\hline
\end{tabular}

*) Mann-Whitney U-test versus control group in the 1. period $(2 \mathrm{p}<0.05)$

**) Mann-Whitney U-test versus fed control group in the 2. period $(2 p<0.05)$

***) Mann-Whitney U-test versus fasted control group in the 2 . period $(2 \mathrm{p}<0.05)$

dase, C1-fructose 1.6-diphosphatase and glucose 6phosphatase were higher in the diabetic group, compared with those in controls when calculated against protein. Unlike Raab (14) we did not find any activity of glucose 6-phosphate dehydrogenase in urine. Glucose 6-phosphatase activity could also not be detected in urine samples.

\section{Discussion}

In accordance with Kuwahara et al. (1) our data on enzymuria confirm the differences between control and diabetic rats not only on diet ad libitum, but also during fasting days. As shown in the results, the diabetic group produced polyuria and urinary enzyme activities which were several times higher than those in controls. Only the activities of alanine aminopeptidase and $\gamma$-glutamyltransferase were decreased in the diabetic group. In contrast to Kuwahara et al. (1) we also found increased activities for lactate dehydrogenase in the urine of diabetic rats. In addition to elevated or decreased kidney-specific urinary enzyme activities, the urinary electrolytes, urine vol- ume, total protein, creatinine and glucose were significantly increased. The portion of total urinary protein consisting of enzymatic protein originating in kidney could not be precisely specified. In addition to lactate dehydrogenase and pyruvate kinase, the activities of enzymes involved in carbohydrate metabolism, except glucose 6-phosphate dehydrogenase, were increased in renal cortical tissue.

The most remarkable microscopic finding in the kidneys of severely diabetic rats consisted of glycogen storage in tubular cells of the straight cortical parts of the distal tubuli, the development of so-called Armanni-Ebstein cells. As is generally known, diabetes causes a decrease in accumulation of liver glycogen and an increase of this polymer in kidney. Our findings are in agreement with Schorr (15) who showed that insulin deficiency followed by metabolic acidosis causes a reversible shift between synthetic and catabolic enzymatic action in glycogen metabolism. Kidneys contain relatively low concentrations of glycogen. The microscopically visible augmentation of glycogen deposition started when hyperglycaemic values between 10.5 and $14.5 \mathrm{mmol} / \mathrm{l}$ occurred. 
Tab. 2. Urinary excretion of electrolytes, glucose $(\mu \mathrm{mol} / \mathrm{d} \cdot \mathrm{kg}$ body weight) creatinine, ( $\mu \mathrm{mol} / \mathrm{d} \cdot \mathrm{kg}$ body weight) total protein, $(\mathrm{mg} / \mathrm{d} \cdot \mathrm{kg}$ body weight) and body weight $(\mathrm{g})$ in male control and in streptozotocin-diabetic Wistar rats.

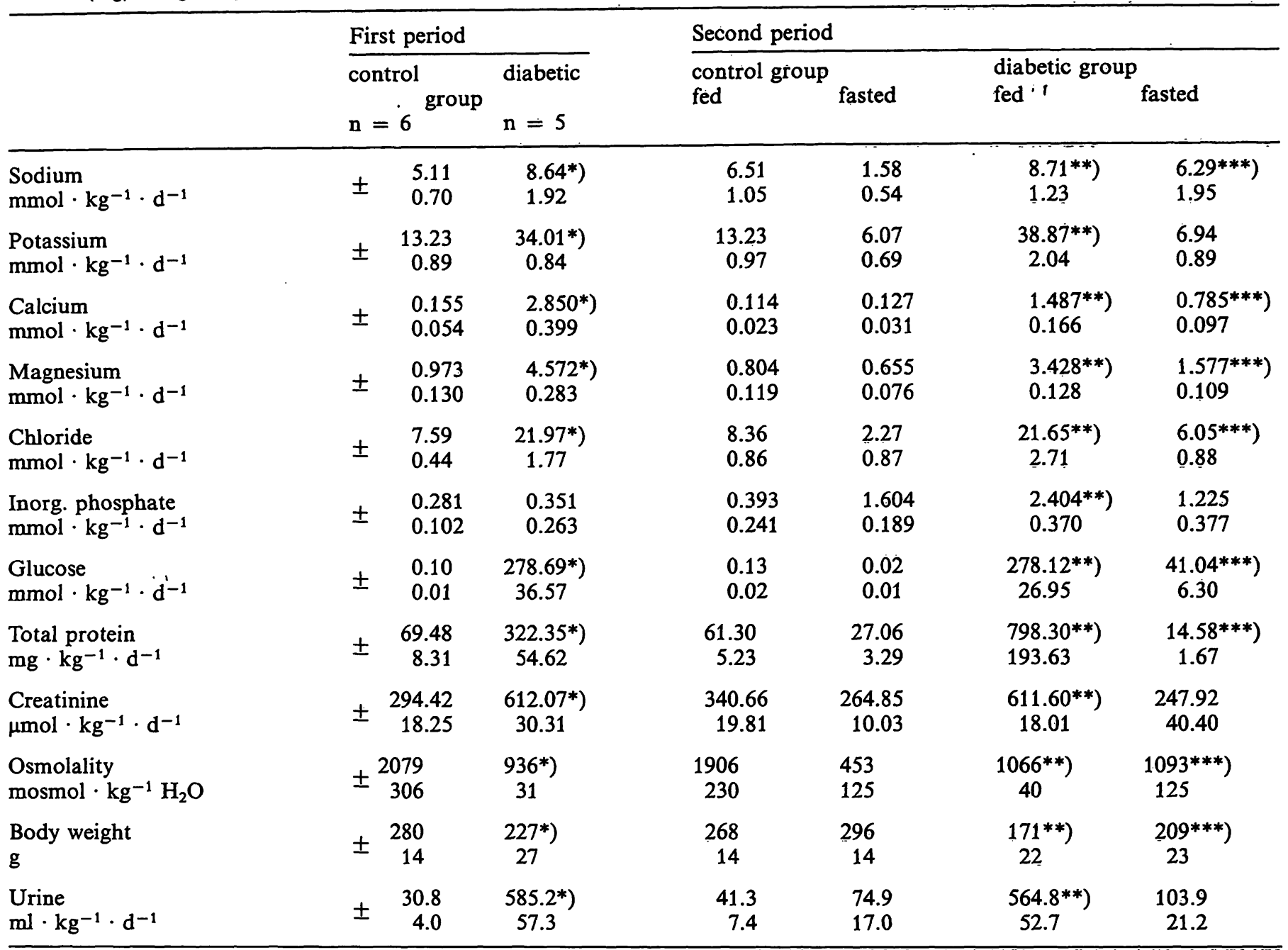

*) Mann-Whitney U-test versus control group in the 1. period $(2 \mathrm{p}<0.05)$

**) Mann-Whitney U-test versus fed control group in the 2. period $(2 \mathrm{p}<0.05)$

***) Mann-Whitney U-test versus fasted control group in the 2 . period $(2 \mathrm{p}<0.05)$

Figure 2 from the kidney of the animal with mild diabetes confirms this view. In kidneys from streptozotocin diabetic rats with about 5-fold increased blood glucose values, Khandelwal et al. (16) detected an approximately 30 -fold increase in glycogen.

Lysosomal enzyme activities have been determined in kidney tissue and serum of streptozotocin-diabetic rats and in urine and serum of diabetic patients with regard to the onset of diabetic microangiopathy. Fushimi \& Tarui (17) reported on decreased N-acetyl$\beta$ - $D$-glucosaminidase activities in renal tissue and elevated $\mathrm{N}$-acetyl- $\beta-D$-glucosaminidase levels in the serum of diabetic rats. In contrast to these results, we did not find a significant difference for $\mathrm{N}$-acetyl$\beta$ - $D$-glucosaminidase and acid phosphatase in the cortical tissue of the kidneys between diabetic and control rats, whereas the urinary $\mathrm{N}$-acetyl- $\beta$ - $D$-glucosaminidase and acid phosphatase activities were significantly higher in diabetic than in control animals.

Østerby et al. (18) studied the glomeruli of streptozotocin-diabetic rats quantitatively on days 4 and 47 after streptozotocin administration. The animals showed enlarged kidneys, growth of glomeruli and glomerular capillaries with an increase in the total volume of basement membrane material. The diabetic metabolic derangement interfered markedly with the basement membrane metabolism, most likely speeding up the rate of synthesis. The glomerular change set in very fast, but it also seemed to stabilize again quite quickly since no further accumulation was demonstrable after the first 4-day period. The steeply 
Tab. 3. Enzymes (U/g protein) in the cortex of male control and streptozotocin-diabetic Wistar rats.

\begin{tabular}{|c|c|c|}
\hline & $\begin{array}{l}\text { Control } \\
\text { group } \\
n=6\end{array}$ & $\begin{array}{l}\text { Diabetic } \\
\text { group } \\
n=5\end{array}$ \\
\hline Alanine aminopeptidase & $\begin{array}{r}13.24 \\
\pm \quad 2.54\end{array}$ & $\begin{array}{c}\left.10.66^{*}\right) \\
0.76\end{array}$ \\
\hline$\gamma$-Glutamyltransferase & $\begin{array}{r}232.80 \\
\pm \quad 25.43\end{array}$ & $\begin{array}{r}267.12 \\
35.07\end{array}$ \\
\hline $\mathrm{N}$-Acetyl- $\beta$ - $D$-glucosaminidase & $\begin{array}{r}150.43 \\
\pm \quad 21.90\end{array}$ & $\begin{array}{r}185.33 \\
16.28\end{array}$ \\
\hline Acid phosphatase & $\begin{array}{r}49.67 \\
\pm \quad 5.73\end{array}$ & $\begin{array}{r}54.55 \\
5.15\end{array}$ \\
\hline Lactate dehydrogenase & $\pm \begin{array}{r}2620.45 \\
80.05\end{array}$ & $\begin{array}{c}\left.4144.10^{*}\right) \\
652.29\end{array}$ \\
\hline$\beta$-Glucosidase & $\begin{array}{r}15.93 \\
\pm \quad 0.38\end{array}$ & $\begin{array}{c}\left.19.05^{*}\right) \\
1.33\end{array}$ \\
\hline Pyruvate kinase & $\begin{array}{r}167.23 \\
\pm \quad 14.13\end{array}$ & $\begin{array}{c}\left.251.60^{*}\right) \\
42.16\end{array}$ \\
\hline C1 Fructose 1.6-diphosphatase & $\begin{array}{r}48.78 \\
\pm \quad 4.74\end{array}$ & $\begin{array}{c}\left.67.09^{*}\right) \\
4.74\end{array}$ \\
\hline Glucose 6-phosphatase & $\begin{array}{r}23.52 \\
\pm \quad 8.63\end{array}$ & $\begin{array}{c}\left.43.28^{*}\right) \\
7.90\end{array}$ \\
\hline Glucose 6-phosphate dehydrogenase & $\begin{array}{r}23.50 \\
\pm \quad 1.35\end{array}$ & $\begin{array}{r}23.12 \\
1.54\end{array}$ \\
\hline
\end{tabular}

*) Mann-Whitney U-test $(2 \mathrm{p}<0.05)$ increased urinary flow up to nearly 20 times its normal volume within the first three days after streptozotocin injection induced these glomerular changes. Hence, it follows that at the same time point in our investigations the glomerular hyperplastic process with an increase in the size of filtration surface was already complete and an augmentation of PAS-positive material in the mesangium was not detectable.

From these findings we conclude that tubular cells most likely produced the elevated $N$-acetyl- $\beta$ - $D$-glucosaminidase and acid phosphatase activities independently of the development of diabetic microangiopathy at this point of time. Moreover, our results indicate that insulin deficiency followed by hyperglycaemia, polyuria, glucosuria and metabolic acidosis is responsible for the metabolic, functional and structural abnormalities of the kidney.

\section{Acknowledgement}

We would like to thank Ms. Edith Dichtl, Ms. Rosel Heun and Mrs. Ursula Schwarzer for their skillful assistance, Dr. Gerlinde Berscheid for the analysis of total protein, and Mr. Vitus Maler$c z y k$ for helpful discussions in preparing the manuscript.

\section{References}

1. Kuwahara, M., Lyons, S., Rosenblit, P. \& Metzger, R. (1976) Proc. Soc. Exp. Biol. Med. 153, 305-308.

2. Belfiore, F., Vecchio, L. L., Napoli, E. \& Borzi, V. (1974) Clin. Chem. 20, $1229-1230$.

3. Bomback, F. M., Nakagawa, S., Kumin, S. \& Nitowsky, H. M. (1976) Diabetes 25, 420-427.

4. Berscheid, G., Grötsch, H.,Hropot, M., Klaus, E. \& Mattenheimer, H. (1983) J. Clin. Chem. Clin. Biochem. 21, $799-804$.

5. Szaszz, G. (1970) Z. Klin. Chem. Klin. Biochem. 8, 1-8.

6. Optimized standard methods of Deutsche Ges. f. Klinische Chemie: (1970) Z. Klin. Chem. Klin. Biochem. 8, 658-660 and (1972) 10, 182-192.

7. Beisenherz, G., Boltze, H. J., Bücher, Th., Czok, R., Garbade, K. H., Meyer-Arendt, E. \& Pfleiderer, G. (1953) Z. Naturforsch. $8 b, 555=577$.

8:'Krause, G. H. \& Bassham, J. A. (1969) Biochim. Biophys. Acta 172, 553-565 and Buchanan, B. B., Kalberer, P. P. \& Arnon, D. I. (1968) Fed. Proc. 27, 344.

9. Kornberg, A. \& Horecker, B. L. (1955) Meth. Enzymol. I, $323-334$
10. Andersch, M. \& Szczypinski, A. (1947) Am. J. Clin. Pathol. $17,571-574$

11. Fishman, W. H. \& Lerner, F. (1953) J. Biol. Chem. 200, 89-97.

12. Hösel, W. (1975) Hoppe-Seylers Z. Physiol. Chem. 356, 1265-1275

13. Baginski, E. S., Foa, P. P. \& Zak, B. (1967) Clin. Chim. Acta 15, 155-158.

14. Raab, W. (1981) Internat. J. Clin. Pharmacol. Therapy and Toxicol. 19, 9-10.

15. Schorr, W., Inaugural Dissertation 1984, Johann Wolfgang Goethe-Universität Frankfurt/M.

16. Khandelwal, R. L., Zinman, S. M. \& Knull, H. R. (1979) Biochem. Biophys. 179, 310-316.

17. Fushimi, H. \& Tarui, S. (1976) J. Biochem. 79, 271-275.

18. Østerby, R., Gunderson, H. J. G., Gøtzsche, O., Hirose, K., Kroustrup, J. P., Rasch, R. \& Seyer-Hansen (1982) New Trends in Basement Membrane Research, Raven Press New York, pp. 203-208.

19. Sachs, L. (1982) Applied Statistics; A Handbook of Techniques, Springer-Verlag New York.

\author{
Dr. Horst Grötsch \\ Hoechst AG \\ D-6230 Frankfurt/M. 80
}


$\because$ 